\title{
Analisis Pendapatan Usaha Sapi Potong Pola Penggemukan Pada Anggota Kelompok Tani Ternak Bangunrejo II Di Desa Polosiri Kecamatan Bawen Kabupaten Semarang \\ (Income Analysis of Beet Cattle Fattening Farm in The Members of Bangunrejo II Cattle Farmer Grup in Polisiri Village of Bawen Subdistrict of Semarang Regency)
}

\author{
Gitty Nadya Putri, Djoko Sumarjono dan Wiludjeng Roessali \\ Program Studi S1 Agribisnis, Fakultas Peternakan dan Pertanian, \\ Kampus drh. R. Soejono Koesoemowardojo Tembalang, Semarang, Indonesia \\ Email: gittynadya1234@gmail.com
}

Diterima 20 Maret 2019, disetujui 26 Mei 2019

\begin{abstract}
ABSTRAK
Penelitian ini bertujuan untuk menganalisis pendapatan, profitabilias dan menganalisis faktorfaktor yang mempengaruhi pendapatan bersih usaha penggemukan sapi potong anggota Kelompok Tani Ternak Bangunrejo II di Desa Polosiri Kecamatan Bawen Kabupaten Semarang. Metode penelitian yang digunakan adalah sensus 59 orang. Penelitian dilaksanakan pada bulan Oktober-November 2018 di Desa Polosiri Kecamatan Gunungpati Kabupaten Semarang. Daerah penelitian ditentukan secara purposive. Analisis data menggunakan analisis regresi linier berganda dan uji beda one sample t-test. Hasil penelitian menunjukkan pendapatan usaha penggemukan sapi potong sebesar Rp 535.310 per bulan per ekor dan profitabilitas sebesar $18 \%$. Uji t menunjukkan pengalaman usaha, biaya tenaga kerja, biaya pakan hijauan, biaya pakan tambahan, biaya bakalan, dan lama periode mempengaruhi pendapatan, sedangkan skala usaha dan pendidikan tidak mempengaruhi pendapatan. Secara serempak seluruh variabel mempengaruhi pendapatan dengan nilai Adjusted $\mathrm{R}^{2}$ sebesar $62,2 \%$. Kesimpulan dari penelitian ini adalah secara signifikan pendapatan usaha penggemukan sapi potong lebih rendah dari upah minimum regional Kabupaten Semarang, profitabilitas usaha penggemukan sapi potong lebih tinggi dari suku bunga deposito bank, variabel pengalaman usaha, biaya tenaga kerja, biaya pakan hijauan, biaya pakan tambahan, biaya bakalan, dan lama periode berpengaruh terhadap pendapatan. Saran penelitian ini yaitu diperlukan kemudahan bagi peternak untuk mengakses kredit maupun progam bantuan lainnya untuk menunjang usaha peternakan.
\end{abstract}

Kata kunci: pendapatan; penggemukan; profitabilitas; sapi potong

\begin{abstract}
The research purposed to analyze the income, profitability and factors influencing net income in the members of Bangunrejo II cattle farmer group in Polosiri Village of Bawen Subdistrict of Semarang Regency. The method used in this study was census with 31 respondents. This study was conducted on October-November 2018 in Polosiri Village of Bawen Subdistrict of Semarang Regency, which was selected purposively. The data were analyzed by using multiple linear regression and one sample t-test. The result showed that the income of beef cattle fattening farm was IDR 535.310 per month per head and the profitability was $18 \%$. The $t$ test showed that business exceprience, the cost of labor, the cost of forage feed, the cost of additional feed, the cost of purchasing beef cattle and the period of raising cattle significantly influence net income, while business scale and education not significantly influence net
\end{abstract}


income. All independent variables significantly influenced net income with Adjusted $\mathrm{R}^{2} 62,2 \%$. The conclusion of this study was net income of beef cattle fattening farm is lower than Semarang Regency minimum wage, the profitability of beet cattle fattening farm is higher than bank deposit interest rates, and business exceprience, the cost of labor, the cost of forage feed, the cost of additional feed, and the cost of purchasing beef cattle and the period of raising cattle influence net income. The suggestion of this study was that farmers need the ease of accessing credit and other assistance programs to support beef cattle fattening farm.

Keyword: income; fattening; profitability; beef cattle

\section{PENDAHULUAN}

Usaha peternakan sapi potong pada umumnya dikembangkan di wilayah pedesaan yang dikelola langsung oleh masyarakat baik secara berkelompok maupun perseorangan. Masyarakat pedesaan menjadikan usaha sapi potong sebagai sumber penghasilan utama maupun sampingan yang dapat menunjang perekonomian keluarga. Pola usaha penggemukan sapi potong telah banyak dilakukan oleh masyarakat, dengan sistem ini sapi umur muda dipelihara dengan dikandangkan secara terus menerus diberi pakan dan dipelihara dengan tujuan untuk meningkatkan volume daging dengan mutu yang baik dalam kurun waktu yang relatif singkat.

Usaha penggemukan sapi potong dapat dijalankan dengan memasukkan input produksi yang akan menghasilkan output produksi berupa penerimaan dan pendapatan usaha. Pendapatan yang diterima peternak dapat dipengaruhi oleh beberapa hal antara lain: skala usaha, pengalaman usaha, pendidikan, biaya tenaga kerja, biaya pakan hijauan, biaya pakan tambahan, harga bakalan serta lama periode penggemukan. Hal ini sesuai penelitian yang telah dilakukan oleh Indrayani dan Andri (2018) bahwa faktorfaktor yang mempengaruhi pendapatan usaha ternak sapi potong adalah jumlah biaya yang dikeluarkan dalam usaha ternak sapi potong, skala usaha atau jumlah ternak, pengalaman beternak dan pendidikan.

Kelompok tani ternak (KTT) merupakan salah satu cara pendekatan yang dilakukan untuk meningkatkan produktivitas ternak dan peternak di pedesaan. Kelompok tani ternak menjadi sarana baik untuk pembinaan dan penyuluhan bagi peternak untuk meningkatkan keterampilan, sikap dan pengetahuan anggota. Abdullah (2008) menyatakan Kelompok tani ternak diharapan menjadi sarana untuk mempermudah pembinaan peternak oleh instansi atau lembaga yang terkait disamping bagi peternak dijadikan wahana untuk meningkatkan pengetahuan dan keterampilan anggota. Adanya kelompok tani ternak akan membantu anggota untuk meningkatkan usaha penggemukan sapi potong yang akan meningkatkan pendapatan peternak dari usaha penggemukan sapi potong yang dijalankan.

Kecamatan Bawen berada di wilayah Kabupaten Semarang yang memiliki luas wilayah 46,570 km2. Desa Polosiri merupakan salah satu wilayah di Kecamatan Bawen dengan luas wilayah 5,86 km2. Kelompok Tani Ternak Bangunrejo II memiliki 59 anggota. Kelompok Tani Ternak Bangunrejo II merupakan kelompok yang memiliki kinerja baik dibuktikan dengan sejumlah pretasi sebagai juara 1 KTT sapi potong tingkat Jawa Tengah tahun 2012 dan juara 2 lomba agribisnis sapi potong tingkat nasional pada tahun 2013, saat ini masih berkembang dengan pola penggemukan sehingga diperlukan perhitungan untuk mengetahui sejauh mana usahatani dapat memberikan keuntungan bagi peternak.

Tujuan penelitian ini adalah 1) Menganalisis pendapatan usaha penggemukan sapi potong, 2) Menganalisis profitabilitas usaha penggemukan sapi potong, 3) Menganalisis faktor-faktor yang mempengaruhi pendapatan bersih usaha penggemukan sapi potong. 


\section{METODE PENELITIAN}

Penelitian ini dilaksanakan pada bulang Oktober sampai November 2018 di KTT Bangunrejo II di Desa Polosiri Kecamatan Bawen Kabupaten Semarang. Metode penentuan lokasi menggunakan metode purposive atau sengaja dengan pertimbangan Kelompok Tani Ternak Bangunrejo II memiliki prestasi sebagai juara 1 KTT sapi potong tingkat Jawa Tengah tahun 2012 dan juara 2 lomba agribisnis sapi potong tingkat nasional pada tahun 2013. Responden ditetapkan secara sensus dengan menjadikan seluruh populasi menjadi sampel yaitu anggota KTT Bangunrejo II yang berjumlah 59 orang.

Data yang dikumpulkan pada penelitian ini adalah data primer dan data sekunder. Data primer diperoleh dari hasil pengamatan langsung dan wawancara kepada responden dengan panduan kuesioner. Data meliputi penerimaan dari usaha sapi potong yang dijalankan, biaya yang dikeluarkan selama proses produksi serta sumber modal yang diperoleh. Data sekunder diperoleh dari dinas terkait serta berbagai literatur yang relevan dengan penelitian ini seperti harga jual bobot hidup sapi perkilo serta suku bunga bank.

Data yang terkumpul kemudian dianalisis secara deskriptif kuantitatif menggunakan rumus-rumus untuk mengetahui pendapatan yang diterima peternak dan profitabilitas anggota KTT Bangunrejo II.

1. Rumus pendapatan sebagai berikut (Soekartawi, 2003):

$$
\begin{aligned}
\mathrm{TC} & =\mathrm{FC}+\mathrm{VC} \\
\mathrm{TR} & =\mathrm{P} \times \mathrm{Y} \\
\pi & =\mathrm{TR}-\mathrm{TC}
\end{aligned}
$$

Keterangan:

$\pi=$ Pendapatan usaha penggemukan sapi potong (Rp/Ekor/Bulan)

$\mathrm{TR}=$ Total penerimaan (total revenue) (Rp/Ekor/Bulan)

$\mathrm{TR}=$ Total biaya $\quad($ total cost $)$ (Rp/Ekor/Bulan)
$\mathrm{P} \quad=$ Harga jual (price) (Rp/Ekor/Bulan)

$\mathrm{Y}=$ Kuantitas produksim (Ekor)

$\mathrm{FC}=$ Biaya tetap (fix cost) $(\mathrm{Rp} /$ Ekor/Bulan)

$\mathrm{VC}=$ Biaya Variabel (variable cost) (Rp/Ekor/Bulan)

2. Rumus profitabilitas sebagai berikut (Ekowati et al., 2014):

Profitabilitas $=\frac{\text { Laba }(\mathrm{Rp} / \text { Ekor/Bulan })}{\text { Biaya }(\mathrm{Rp} / \text { Ekor/Bulan })} \times 100 \%$

3. Faktor- faktor yang mempengaruhi pendapatan dapat diketahui dengan menggunakan analisis regresi linear berganda. Data dianalisis dengan menggunakan penyelesaian software SPSS 17. Persamaan regresi digambarkan sebagai berikut:

$$
\begin{aligned}
\mathrm{Y}= & \mathrm{a}+\mathrm{b}_{1} \mathrm{X}_{1}+\mathrm{b}_{2} \mathrm{X}_{2}+\mathrm{b}_{3} \mathrm{X}_{3}+\mathrm{b}_{4} \mathrm{X}_{4}+\mathrm{b}_{5} \mathrm{X}_{5}+ \\
& \mathrm{b}_{6} \mathrm{X}_{6}+\mathrm{b}_{7} \mathrm{X}_{7}+\mathrm{b}_{8} \mathrm{X}_{8}+\mathrm{e}
\end{aligned}
$$

Keterangan:

$\mathrm{Y}=$ Pendapatan usaha penggemukan sapi potong (Rp/Ekor/Bulan)

$\mathrm{a}=$ Konstanta

$\mathrm{b}=$ Koefisien regresi

$\mathrm{X} 1=$ Variabel skala usaha (Ekor)

$\mathrm{X} 2=$ Variabel pengalaman usaha (Tahun)

$\mathrm{X} 3=$ Variabel pendidikan (variable dummy) tidak sekolah/tamat SD, SD, SMP: 0; SMA, S1=1)

$\mathrm{X} 4=$ Variabel biaya tenaga kerja (Rp/Ekor/Bulan)

$\mathrm{X} 5=$ Variabel biaya pakan hijauan (Rp/Ekor/Bulan)

$\mathrm{X} 6=$ Variabel biaya pakan konsentrat (Rp/Ekor/Bulan)

$\mathrm{X} 7=$ Harga bakalan $(\mathrm{Rp})$

$\mathrm{X} 8=$ Lama periode penggemukan (Bulan)

$\mathrm{e}=$ Kesalahan pengganggu

\section{HASIL DAN PEMBAHASAN}

\section{Karakteristik Responden}

Peternak yang dijadikan responden dalam penelitian ini adalah seluruh anggota 
Tabel 1. Karakteristik Peternak Sapi potong Anggota KTT Bangunrejo II

\begin{tabular}{lcc}
\hline \multicolumn{1}{c}{ Karakteristik } & Jumlah Responden & Persentase \\
\hline Umur (Tahun) & $-----O r a n g-----$ & $----\%$----- \\
$31-40$ & 2 & 3 \\
$41-50$ & 12 & 22 \\
$51-60$ & 37 & 63 \\
$>60$ & 7 & 12 \\
Pendidikan & & \\
SD & 43 & 73 \\
SMP & 9 & 15 \\
SMA & 5 & 8 \\
Diploma & 1 & 2 \\
Sarjana & 1 & 2 \\
Pengalaman Usaha (Tahun) & & \\
1-15 & 12 & 20 \\
$16-30$ & 35 & 59 \\
$31-45$ & 12 & 20 \\
\hline
\end{tabular}

KTT Bangunrejo II yang menjalankan usaha penggemukan sapi potong. Sebagian besar responden menjalankan usaha penggemukan sapi potong sebagai pekerjaan sampingan selain bertani. Peternak memelihara secara intensif yaitu sapi dikandangkan secara terus menerus hingga sapi dijual.

Berdasarkan Tabel 1 kisaran umur anggota KTT Bangunrejo II 51-60 tahun dengan persentase $63 \%$ dari total responden. Sebaian besar responden berumur kurang dari 60 tahun yang berarti responden masih produktif untuk bekerja karena dalam usia lebih dari 15 tahun dan kurang dari 60 tahun termasuk dalam angkatan kerja. Hal ini sesuai dengan pendapat Otoluwa et al. (2016) bahwa usia yang tergolong produktif dalam artian mampu melaksanakan usahanya berada pada umur 15-60 tahun.

Tingkat pendidikan responden terbesar adalah pada jenjang pendidikan Sekolah Dasar berjumlah 43 orang atau $73 \%$ dari total responden. Tingkat pendidikan responden masih rendah, hal tersebut dapat diketahui dengan membandingkan antara jumlah responden yang tamat Sekolah Dasar dengan responden pada jenjang pendidikan lainnya yang sangat berbeda jauh. Hal ini dikarenakan responden tinggal diwilayah perdesaan sehinggga tingkat pendidikan belum merata.

Sebagian besar responden (59\%) mempunyai pengalaman usaha dalam bidang peternakan selama 16 sampai 30 tahun. Peternak anggota Kelompok Tani Ternak Bangunrejo II telah menjalankan usaha cukup lama karena usaha peternakan yang bersifat tradisional merupakan hasil usaha turun menurun dari orangtua, yang kemudian dilanjutkan oleh anak-anaknya disaat orangtua sudah tidak produktif. Namun, peternakan sapi masih diusahakan secara tradisional yaitu dengan membeli bibit sapi kemudian dipelihara secara intensif untuk meningkatkan volume daging, pemanfaatan sumberdaya produksi dalam peterenakan tradisional belum maksimal seperti pengadaan bibit sapi, pakan, upah tenaga kerja yang belum diperhitungkan dengan baik, sehingga hasil usaha ternak sapi memberikan pendapatan walaupun keuntungan yang diperoleh belum memadai. Hal ini sesuai dengan pendapat Ahmad et al. (2004) bahwa sapi potong yang dipelihara secara tradional banyak diusahakan oleh masyarakat, dimana jumlah kepemilikan ternak dalam skala kecil, modal, keterampilan dan teknologi yang masih terbatas. 


\section{Periode Pemeliharaan}

Periode pemeliharaan sapi potong yang dilakukan oleh peternak anggota Kelompok Tani Ternak Bangunrejo II cukup bervariatif yaitu 3 bulan sampai 10 bulan.

Tabel 2. Periode Periode Pemeliharaan Sapi

\begin{tabular}{llcc}
\hline No & \multicolumn{1}{c}{ Periode } & Jumlah & Persentase \\
\hline & ---Bulan--- & ----Ekor---- & --- $\%$--- \\
1 & 3 Bulan & 7 & 7 \\
2 & 4 Bulan & 9 & 9 \\
3 & 5 Bulan & 6 & 6 \\
4 & 6 Bulan & 24 & 24 \\
5 & 7 Bulan & 18 & 18 \\
6 & 8 Bulan & 15 & 15 \\
7 & 9 Bulan & 9 & 9 \\
8 & 10 Bulan & 12 & 12 \\
\hline \multicolumn{2}{l}{ Total } & 100 & 100 \\
\hline
\end{tabular}

Sebagian besar peternak anggota Kelompok Tani Ternak Bangunrejo II memelihara ternak selama 6 dan 7 bulan sehingga dalam satu tahun memungkinkan untuk menjual 2 ternak. Periode pemeliharaan selama 6 bulan akan mengasilkan produksi yang optimal, karena apabila pemeliharaan yang dijalankan dalam waktu yang relatif lama akan membebani biaya produksi. Hal ini sesuai dengan pendapat Fikar dan Ruhyadi (2010) menyatakan bahwa umumnya usaha penggemukan sapi potong dijalankan dalam waktu relatif singkat sekitar 6 bulan. Hal ini diperkuat dengan penelitian dari Budiraharjo et al. (2011) di Kecamatan Gunungpati Kota Semarang bahwa sapi peranakan Friesian Holstein, Peranakan Ongole dan Simmental yang dipeliraha dalam kurun waktu 6 bulan

Tabel 3. Pertambahan Bobot Badan Harian dapat menghasilkan rata-rata bobot badan $400-470 \mathrm{~kg}$.

\section{Pertambahan Bobot Badan Harian}

Pertambahan bobot badan harian sapi yang dipelihara oleh peternak berbeda-beda tergantung pada bangsa sapi yang dipelihara. Rata-rata pertambahan bobot badan harian sapi Limousin sebesar $0,9058 \mathrm{~kg} /$ hari dan sapi Simmental sebesar $0,9139 \mathrm{~kg} / \mathrm{hari}$, pertambahan bobot badan Limousin dan Simmental penelitian ini masih dibawah ratarata pertambahan bobot badan harian sapi Limousin dan Simmental, sedangkan rata-rata pertambahan bobot badan harian sapi PO sebesar $0,8094 \mathrm{~kg} /$ hari, pertambahan bobot harian tersebut sesuai dengan pertambahan bobot badan harian sapi PO jika dibandingkan dengan hasil penelitian Fikar dan Ruhyadi (2010) diperoleh rata-rata pertambahan bobot badan harian sapi Limousin dan Simmental sebesar 1,2-1,4 kg/hari serta sapi PO sebesar 0,6-0,8 kg/hari. Rata-rata pertambahan bobot badan harian sapi Jawa yang penelitian ini sebesar $0,6468 \mathrm{~kg} /$ hari, pertambahan tersebut telah sesuai dengan pertambahan bobot badan harian sapi Jawa sesuai penelitian Adiwinarti et al., (2011) bahwa pertambahan bobot badan harian sapi Jawa sebesar 0,59-0,72 $\mathrm{kg} /$ hari pada tingkat protein pakan yang berbeda. Sebagian besar responden menjual hasil ternak ke blantik sehingga bobot badan serta harga yang diberikan merupakan harga perkiraan dari blantik.

\begin{tabular}{llccc}
\hline No & \multicolumn{1}{c}{ Bangsa Sapi } & \multicolumn{2}{c}{ Jumlah } & Pertambahan BBH \\
\hline & & -- Orang-- & - -Ekor-- & -----Kg/Hari---- \\
1 & Limousin & 39 & 64 & 0,9058 \\
2 & Simmental & 10 & 13 & 0,9139 \\
3 & Peranakan Ongole (PO) & 13 & 19 & 0,8094 \\
4 & Jawa & 3 & 4 & 0,6468 \\
& Total & & 100 & 3,2759 \\
\hline
\end{tabular}


Analisis Pendapatan Usaha Penggemukan Sapi Potong

Tabel 4. Analisis Pendapatan

\begin{tabular}{lrr}
\hline \hline Keterangan & \multicolumn{1}{c}{ Nilai } & Persentase \\
\hline $\begin{array}{l}\text { Penerimaan } \\
\text { 1. Penjualan }\end{array}$ & - --Rupiah--- & -----\%---- \\
ternak & 376.545 .615 & 99,34 \\
$\begin{array}{l}\text { 2. Penjualan } \\
\text { kotoran }\end{array}$ & 2.500 .000 & 0,66 \\
$\begin{array}{l}\text { Total } \\
\text { penerimaan }\end{array}$ & 379.045 .615 & 100,00 \\
$\begin{array}{l}\text { Biaya } \\
\text { 1. Biaya tetap }\end{array}$ & 6.067 .776 & 1,94 \\
$\begin{array}{l}\text { 2. Biaya } \\
\text { variabel }\end{array}$ & 306.274 .096 & 98,06 \\
$\begin{array}{l}\text { Total biaya } \\
\text { Pendapatan }\end{array}$ & 312.341 .872 & 100,00 \\
$\begin{array}{l}\text { Pendapatan } \\
\text { per responden }\end{array}$ & 53.531 .464 & \\
\hline
\end{tabular}

\section{Biaya Produksi}

Biaya Produksi perbulan yang dikeluarkan oleh peternak terdiri dari biaya tetap yaitu: penyusutan, pajak, iuran, listrik dan transportasi serta biaya variabel yaitu: harga bakalan, pakan, obat-obatan dan air. Total biaya perbulan yang dikeluarkan oleh anggota Kelompok Tani Ternak Bangunrejo II sebesar Rp 312.341.872 per bulan, yang terdiri dari biaya tetap sebesar Rp 6.067.776 per bulan dan biaya variabel sebesar Rp 306.274.096 per bulan. Hal ini sesuai dengan pendapat Shinta (2011) bahwa biaya digunakan produsen untuk proses produksi yang dinyatakan dalam bentuk uang dalam kurun waktu tertentu baik secara tunai maupun diperhitungkan.

\section{Penerimaan}

Besarnya penerimaan usaha penggemukan sapi potong bergantung pada bobot hidup serta harga jual pada saat terjadi proses penjualan. Hal ini sesuai dengan pendapat Rianto dan Purbowati (2011) menyatakan bahwa penerimaan usaha penggemukan sapi sangat bergantung pada pertambahan bobot badan sapi dan harga jual sapi perkilogram bobot badan hidup. Total penerimaan anggota Kelompok Tani Ternak Bangunrejo II sebesar Rp 379.045.615 per bulan, Rata-rata penerimaan yang diterima oleh peternak setiap bulan adalah Rp 6.424.502, yang terdiri dari penerimaan tunai dan diperhitungkan. Hal ini sesuai dengan pendapat dari Ekowati et al. (2014) yang menyatakan bahwa penerimaan usahtani adalah semua nilai uang yang diterima dari usahatani baik secara tunai maupun diperhitungkan dalam kurun waktu tertentu.

\section{Pendapatan}

Pendapatan bersih merupakan selisih dari penerimaan dengan biaya yang dikeluarkan untuk usahatani yang telah ditambah dengan upah tenaga kerja keluarga, apabila petani memiliki modal pinjaman dari luar maka bunga modal luar diperhitungkan. Hal ini sesuai dengan pendapat Ekowati et al. (2014) yang menyatakan bahwa pendapatan bersih merupakan selisih dari penerimaan dengan biaya alat luar ditambah upah tenaga kerja keluarga. Total pendapatan bersih yang diperoleh anggota Kelompok Tani Ternak Bangunrejo II sebesar Rp 53.531.026, dengan rata-rata pendapatan bersih yang diterima oleh peternak dalam setiap bulan adalah sebesar Rp 907.306, dengan kepemilikan ratarata per responden dua ekor maka pendapatan peternak per responden per ekor adalah sebesar $\mathrm{Rp}$ 535.315. Pendapatan ini masih lebih tinggi bila dibandingkan dengan penelitian Budiraharjo et al. (2011) bahwa pendapatan rata-rata anggota KTT di Kecamatan Gunungpati Kota semarang sebesar Rp 258.589 dalam satu bulan.

\section{Profitabilitas}

Profitabilitas usaha penggemukan sapi potong yang dilakukan oleh anggota Kelompok Tani Ternak Bangunrejo II sebesar $18 \%$. Profitabilitas merupakan hasil bagi dari pendapatan bersih yang diterima oleh peternak dengan biaya yang dikeluarkan oleh peternak. Profitabilitas usahatani sapi potong yaitu $14 \%$ lebih tinggi dari suku bunga 
deposito bank, yang berarti bahwa usahatani penggemukan sapi potong layak karena menguntungkan atau profitabel. Hal ini sesuai dengan pendapat dari Budiraharjo et al. (2011) yang menyatakan bahwa nilai profitabilitas yang lebih besar dari suku bunga bank dapat dinyatakan usaha tersebut layak dilakukan karena mampu menghasilkan keuntungan.

\section{Faktor-Faktor Yang Mempengaruhi Pendapatan Usaha Penggemukan Sapi Potong}

Analisis faktor-faktor yang mempengaruhi usaha penggemukan sapi potong menggunakan analisis regresi linier berganda, yang menjadi variabel bebas (independent) adalah skala usaha (X1), pengalaman usaha (X2), pendidikan (X3), biaya tenaga kerja (X4), biaya pakan hijauan (X5), biaya pakan tambahan (X6), biaya bakalan (X7), dan lama periode (X8), sedangkan yang mendjadi variabel terikat (dependent) adalah pendapatan bersih (Y).

Berdasarkan hasil analisis regresi pada Tabel 5. dapat diketahui bahwa nilai $F$ signifikansi sebesar $0,000^{\mathrm{a}}$ yang berarti bahwa semua variabel bebas (independen) yaitu skala usaha, pengalaman usaha, pendidikan, biaya tenaga kerja, biaya pakan hijauan, biaya pakan tambahan, biaya bakalan dan lama periode pemeliharaan secara serempak berpengaruh terhadap variabel terikat (dependen) yaitu pendapatan bersih usahatani pada tingkat kepercayaan 95\%. Hal ini sesuai dengan pendapat Nuraina (2012) yang menyatakan bahwa uji $\mathrm{F}$ digunakan untuk menguji apakah variabel independen berpengaruh secara bersama-sama atau simultan terhadap variabel dependennya.

Nilai Adjusted R Square adalah 0,622 atau $62,2 \%$ menunjukkan bahwa sumbangan pengaruh variabel bebas terhadap variabel terikat yaitu pendapatan bersih sebesar $62,2 \%$ dan sebesar 37,8\% variabel terikat dijelaskan oleh variabel lain diluar variabel yang telah ditentukan. Hal ini sesuai dengan pendapat Cahyawati et al. (2009) yang menyatakan bahwa nilai Adjusted R-Square yang mendekati satu berarti variabel bebas memberikan hampir seluruh informasi untuk memprediksi variabel terikat.

Secara parsial nilai signifikansi $\mathrm{t}$ pada Tabel 5. menunjukkan variabel pengalaman usaha, biaya tenaga kerja, biaya pakan hijauan, biaya pakan tambahan, biaya bakalan, dan lama periode pemelihiharaan berpengaruh secara signifikan terhadap pendapatan, sedangkan variabel skala usaha dan pendidikan tidak berpengaruh secara

Tabel 5. Hasil Analisis Regresi Linier Berganda

\begin{tabular}{lcrl}
\hline \multicolumn{1}{c}{ Variabel } & Koefisien Regresi & t hitung & Signifikansi \\
\hline Konstan & 5.555 & 8.502 & .000 \\
Skala Usaha (X1) & .014 & .591 & .556 \\
Pengalaman Usaha (X2) & -.003 & -2.934 & $.004^{*}$ \\
Pendidikan (X3) & -.031 & -1.434 & .155 \\
Biaya Tenaga kerja (X4) & -.418 & -2.905 & $.005^{*}$ \\
Biaya Pakan Hijauan (X5) & -.032 & -2.919 & $.004^{*}$ \\
Biaya Pakan Tambahan (X6) & -.099 & -2.474 & $.015^{*}$ \\
Biaya Bakalan (X7) & .454 & 8.437 & $.000^{*}$ \\
Lama Periode (X8) & -.023 & -2.059 & $.042^{* *}$ \\
\hline F hitung & 21.359 & & \\
F Signifikansi & $.000^{\mathrm{a} *}$ & & \\
Adjusted $\mathrm{R}^{2}$ & .622 & & \\
\hline Keterangan : $*$ = Signifikan pada 1\% & & & \\
& & & \\
\end{tabular}


nyata terhadap pendapatan. Variabel skala usaha (X1) tidak berpengaruh terhadap pendapatan bersih dan memiliki koefisien regresi sebesar 0.014 bernilai nilai positif, Setiap kenaikan 1 satuan skala usaha akan mengurangi pendapatan bersih sebesar 0.014. Jika peternak mampu untuk meningkatkan jumlah sapi yang dimiliki dapat dijadikan sebagai indikator keberhasilan usaha peternakan sapi karena dapat meningkatkan pendapatan peternak. Hal ini sesuai dengan pendapat Murwanto (2008) yang menyatakan bahwa meningkatnya jumlah sapi yang dimiliki maka jumlah sapi yang dijual akan bertambah jumlah sapi yang dijual, dengan demikian pendapatan meningkat.

Variabel pengalaman usaha

berpengaruh terhadap pendapatan bersih dan memiliki koefisien regresi sebesar -0.003 bernilai negatif, artinya setiap kenaikan 1 satuan pengalaman beternak akan menurunkan pendapatan bersih sebesar -0.003. Hal ini disebabkan responden yang berpengalaman singkat mendapatkan pendapatan yang lebih besar dari responden yang memiliki pengalaman lama, responden yang berpengalaman singkat sudah mulai berorientasi pada profit serta kepemilikan ternak yang lebih banyak sehingga dapat melakukan penjualan ternak secara berkala, responden yang berpengalaman lama memiliki pengalaman yang memadani namun tetap menjalankan usahanya dengan kebiasaan-kebiasaan lama dan masih berorientasi bahwa ternak merupakan suatu investasi sehingga kepemilikan ternak tidak berkembang, sehingga akan melakukan penjualan ketika dibutuhkan saja. Hal ini sesuai dengan penelitian yang dilakukan oleh Triastono et al. (2013) yang menyatakan bahwa peningkatan satu tahun lama beternak akan menurunkan pendapatan usaha, dikarenakan banyak peternak yang mempunyai jumlah ternak yang banyak dengan pengalaman beternak yang singkat, sebalikanya peternak dengan lama beternak cukup lama namun jumlah ternak yang dimiliki sedikit.

Variabel Pendidikan (X3) tidak berpengaruh terhadap pendapatan bersih dan memilikik koefisien regresi sebesar -0.031 bernilai negatif. Setiap kenaikan 1 satuan pendidikan akan menurunkan pendapatan bersih sebesar -0.031. Pembelajaran yang di dapatkan di pendidikan formal oleh peternak tidak dapat seluruhnya diaplikasikan dalam usaha peternakan, sehingga peternak tidak membutuhkan pendidikan formal yang tinggi untuk dapat menjalankan usahanya. Hal ini sesuai denga pendapat Sahala (2016) yang menyatakan bahwa peternak yang tidak memerlukan pendidikan formal yang tinggi karena pendidikan yang rendah dan dilengkapi oleh pendidikan non formal maka peternak dapat menjalankan usahanya.

Variabel biaya tenaga kerja (X4) berpengaruh terhadap pendapatan bersih dan memiliki koefisien regresi sebesar -0.418 bernilai negatif, artinya setiap kenaikan 1 satuan biaya tenaga kerja akan menurunkan pendapatan bersih sebesar -0.418. Tenaga kerja yang dipergunakan untuk usaha sapi potong tradisional umumnya adalah tenaga kerja keluarga yang dapat terdiri dari laki-laki atau perempuan yang diperhitungkan dalam bentuk biaya non tunai, sehingga apabila peternak mencurahkan waktunya untuk bekerja di kandang maka biaya tanaga kerja akan meningkat pula yang akan menyebabkan pendapatan usaha berkurang. Hal ini sesuai dengan pendapat Darmawi (2012) yang menyatakan bahwa biaya tenaga kerja berkontribusi dalam pendapatan, walaupun tidak pernah dibayarkan, namun biaya tenaga kerja tetap diperhitungkan dalam bentuk non tunai.

Variabel biaya pakan hijauan (X5) berpengaruh terhadap pendapatan bersih dan memiliki koefisien regresi sebesar -0.032 bernilai negatif. Setiap kenaikan 1 satuan biaya pakan hijauan akan menurunkan pendapatan bersih sebesar -0.032. Pakan hijauan yang diberikan oleh petenak tradisional sering kali tidak sesuai dengan kebutuhan ternak. Hijauan yang digunakan oleh peternak merupakan hasil mencari rumput di sawah atau hutan, sehingga dalam perhitungan biaya pakan hijauan dikonversi 
dari lamanya peternak mencari rumput dengan upah kerja, dalam penelitian ini ratarata peternak mencari rumput sekitar 1-2 jam per hari. Walaupun peternak mencari rumput sendiri namun dalam perhitungan pendapatan dianggap membeli, apabila peternak semakin lama dalam mencari hijauan serta upah kerja meningkat, perhitungan biaya pakan hijauan juga akan meningkat yang akan mengurangi pendapatan yang diperoleh peternak. Hal ini sesuai dengan pendapat Hastuti (2008) yang menyakatan bahwa semua hijauan yang mencari sendiri dianggap membeli.

Variabel biaya pakan tambahan (X6) berpengaruh terhadap pendapatan dan memiliki koefisien regresi sebesar -.099 bernilai negatif. Setiap kenaikan 1 satuan biaya pakan tambahan akan menurunkan pendapatan bersih usaha penggemukan sapi potong sebesar -0.099 . Usaha kereman sapi potong dalam batas waktu tertentu kualitas dan jumlah pakan akan mempengaruhi pendapatan, semakin lama peternak memelihara ternak akan meningkatkan pengeluaran peternak untuk membeli bahan pakan tambahan yang akan membani biaya produksi. Hal ini sesuai dengan pendapat Suranjaya (2011) yang menyatakan bahwa pemeliharaan yang dilakukan peternak akan cenderung meningkatkan biaya pakan sehingga akan mengurangi pendapatan yang diperoleh.

Variabel biaya bakalan (X7) berpengaruh terhadap pendapatan bersih dan memiliki koefisien regresi sebesar 0.454 bernilai positif. Setiap kenaikan 1 satuan harga bakalan akan meningkatkan pendapatan bersih sebesar 0.454 . Harga bakalan sapi yang lebih mahal dapat dijadikan patokan bahwa sapi tersebut memiliki faktor genetis yang baik, sapi merupakan modal utama dalam usaha peternakan yang secara kuantitas dan kualitasnya akan mempengaruhi pendapatan Hal ini sesuai dengan pendapat Rahayu (2013) yang menyatakan bahwa biaya yang dikeluarkan peternak rakyat untuk pembelian sapi sangat besar dikarenakan sapi merupakan modal utama yang akan mempengaruhi pendapatan, maka biaya ini sesuai dengan hasil pendapatan yang diperoleh.

Variabel lama periode (X8) berpengaruh terhadap pendapatan bersih usaha dan memiliki koefisien regresi sebesar -0.023 bernilai negatif. Setiap kenaikan 1 satuan lama periode akan mengurangi pendapatan bersih sebesar -0.023 . Semakin lama ternak dipelihara maka akan meningkatkan biaya untuk proses produksinya, sedangkan pertambahan bobot badan ternak setelah mencapai pertumbuhan optimum akan perlahan-lahan menurun, sehingga hal ini akan merugikan peternak. Hal ini sesuai dengan pendapat Suranjaya (2011) yang menyatakan bahwa semakin lama pemeliharaan ternak maka biaya pakan meningkat sementara pertambahan bobot badan ternak akan tetap atau menurun.

\section{SIMPULAN}

Pendapatan bersih dan pendapatan peternak usaha penggemukan sapi potong sebesar Rp 535.310 lebih rendah dari UMR Kabupaten Semarang. Usaha penggemukan sapi potong dikatakan profitabel karena profitabilitas yang diterima petani dari menjalankan usahnya sebesar $18 \%$ lebih tinggi dari suku bunga deposito bank 2018. Seluruh variabel secara serempak berpengaruh nyata terhadap pendapatan bersih usahatani penggemukan sapi potong. Secara parsial pengalaman usaha, biaya tenaga kerja, biaya pakan hijauan, biaya pakan tambahan, biaya bakalan, dan lama periode berpengaruh terhadap pendapatan bersih usaha penggemukan sapi potong, sedangkan skala usaha dan pendidikan tidak berpengaruh terhadap pendapatan bersih usaha penggemukan sapi potong. Saran penelitian ini yaitu diperlukan kemudahan bagi peternak untuk mengakses kredit maupun progam bantuan lainnya untuk menunjang usaha peternakan.

\section{DAFTAR PUSTAKA}

Abdullah, A. 2008. Identifikasi kelas kemampuan kelompok tani ternak di Kecamatan Herlang Kabupaten 
Bulukumba. J. Ilmu Ternak. 8 (1) : 77-82.

Adiwinarti, R., U. R. Fariha dan C. M. S. Lestari. 2011. Pertumbuhan sapi jawa yang diberi pakan jerami padi dan konsentrat dengan level protein berbeda. J. Ilmu Ternak dan Veteriner. 16 (4) : 260-265.

Ahmad, S. N., D. D. Siswansyah dan O. K. S. Swastika. 2004. Kajian sistem usaha ternak sapi potong di Kalimantan Tengah. J. Pengkajian dan Pengembangan Teknologi Pertanian. 7 (2) : 155-170.

Budiraharjo, K., M. Handayani dan G. Sanyoto. 2011. Analisis profitabilitas usaha penggemukan sapi potong di Kecamatan Gunungpati Kota Semarang. J. Ilmu-ilmu Pertanian. 7(1): 1-9.

Cahyawati, D., H. Tanuji dan R. Abdiati. 2009. Efektivitas metode regresi robust penduga welsch dalam mengatasi pencilan pada pemodelan regresi linear berganda. J. Penelitian sains. 12 (1) : 1-7.

Darmawi, D. 2012. Peranan tenaga kerja keluarga dalam usaha pemeliharaan sapi di Kabupaten Tanjung Jabung Barat. J. Ilmu-Ilmu Peternakan. 15 (2) : 48-58.

Ekowati, T., D. Sumarjono., H. Setiyawan dan E. Prasetyo. 2014. Buku Ajar Usahatani. Undip Press, Semarang.

Fikar, S. dan D. Ruhyadi. 2010. Beternak \& Bisnis Sapi Potong. Agro Media Pustaka, Jakarta.

Hastuti, D. 2008. Tingkat keberhasilan inseminasi buatan sapi potong di tinjau dari angka konsepsi dan service per conception. J. Mediagro. 4 (1) : 12-20.
Indrayani, I. dan Andri. 2018. Faktor-faktor yang mempengaruhi pendapatan usaha ternak sapi potong di Kecamatan Sitiung, Kabupaten Dharmasraya. J. Peternakan Indonesia. 20 (3) : 151159.

Murwanto, A. G. 2008. Karakteristik peternak dan tingkat masukan teknologi peternakan sapi potong di Lembah Prafi Kabupaten Manokwari. J. Ilmu Peternakan. 3 (1) : 9-15.

Nuraina, E. 2012. Pengaruh kepemilikan institusional dan ukuran perusahaan terhadap kebijakan hutang dan nilai perusahaan (studi pada perusahaan manufaktur yang terdaftar di BEI). J. Akuntansi. 4 (1) : 51-70.

Otoluwa, M. A., A. H. S. Salendu, A. K. Rintjap dan M. T. Massie. 2016. Prospek pengembangan usaha ternak sapi potong di Kecamatan Bolangitang Timur Kabupaten Bolaang Mongondow Utara. J. Zootek. 36 (1) : 191-197.

Rahayu, E. T. 2013. Analisis pendapatan usaha ternak sapi perah di Kecamatan Cepogo Kabupaten Boyolali. J. Sains Peternakan. 11 (2) : 99-105.

Rianto, E. dan E. Purbowati. 2011. Panduan Lengkap Sapi Potong. Penebar Swadaya, Bogor.

Sahala, J., R. Widiati dan E. Baliarti. 2016. Anailisis kelayakan finansial usaha penggemukan sapi simmental peranakan ongole dan faktor yang berpengaruh terhadap jumlah kepemilikan pada peternakan rakyat di Kabupaten Karanganyar. J. Peternakan. 40 (1) : 75-82.

Shinta, A. 2011. Ilmu Usahatani. UB Press, Malang.

Soekartawi. 2003. Prinsip Ekonomi Pertanian. Rajawali Press, Jakarta. 
Suranjaya, I. G. 2011. Diskripsi dan analisis faktor-faktor produksi yang mempengaruhi pendapatan peternak pada usaha penggemukan sapi bali berskala kecil. J. Ilmiah Peternakan. 14 (1) : 28-32.
Triastono, H., M. Indraji dan S. Mastuti. 2013. Pengaruh faktor sosial ekonomi terhadap pendapatan dan efisiensi usaha peternak kelinci di Kabupaten Banyumas. J. Ilmiah Peternakan. 1 (1) :25-30. 